\title{
Comparisons of Time Spent on Courtship Behavior and Number of Mounts by Boars in Single and Multi-Sire Mating
}

\author{
Hajime Tanida, Yusuke Hara, Toshio Tanaka \\ and Tadashi YosHimoto \\ School of Veterinary Medicine, Azabu University, \\ Sagamihara-shi 229
}

(Received August 18, 1989)

\begin{abstract}
Ninety sows and 12 boars were used in the experiment conducted at a commercial swine farm during summer, 1988. The time spent on courtship behavior and the number of mounts by a boar in a herd of sows injected with gonadotropic hormone were compared in one, two and four-sire mating schemes. At the beginning, a sire group of four Landrace boars was assigned to ten crossbred sows in a mating pen for 24 hours, after which the boars and the sows were separated. The number of boars was then reduced from four to two and from two to one (in turn) at five-day intervals, and the boars (or a boar) were introduced to another ten sows for $24 \mathrm{~h}$. Behaviors during each period were recorded by a time-lapse video recorder. The experiment was replicated three times by using different sire groups. The time spent on courtship behavior and the number of mounts per boar in four-sire mating were significantly longer and more than those in one-sire mating $(P<0.05)$. Boars in two sire mating were sexually more active than the boar in one-sire mating, but the difference was not significant. Sexual activities of boars in the four-sire mating scheme was synchronized throughout $24 \mathrm{~h}$, suggesting the existence of social facilitation in sexual behavior.
\end{abstract}

Jpn. J. Zootech. Sci., 61 (3) : 283-288, 1990

Key words : boars, sexual behavior, multi-sire mating, social facilitation

Some Japanese swine farms are using natural mating as a labor-saving strategy for breeding management where a few boars are placed with a variable number of sows, but the farmers are anxious to know whether social interactions among boars influence each boar's sexual activities. Most previous studies on group mating focused on the inhibiting effects of males' social behavior on the sexual performance in chicken ${ }^{1-3)}$, sheep ${ }^{4-7)}$ and cattle ${ }^{8-10)}$. For instance, BLockEY ${ }^{9)}$ found that mixed-age groups of bulls, when mated to cow herds, achieved lower pregnancy rates than groups of bulls of the same age.
On the other hand, social factors also could affect positively the sexual performance of livestock males. Horrell and KILGOUR ${ }^{11}$ indicated that the presence of the male was an important influence on the female's osetrus behavior in livestock. According to Kilgour et al. ${ }^{12)}$, cow-cow mounting largely ceased when a bull approached, but such behavior might return when he had finished courtship. Social facilitation on courtship and mating behaviors among boars may occur when more than one boar is introduced to several sows. MATTNER et al. ${ }^{13)}$ reported that sexual activity of four bulls per herd was greater than that of 
one bull alone in herds of Polled Hereford cattle.

In swine, it is not well known how many boars are necessary to induce active mating behavior in sow herds of size. Therefore, the objective of the experiment was to compare the courtship and mating behaviors of boars in one, two and four-sire mating in the herd of sows.

\section{Materials and Methods}

The experiment was conducted at the swine farm run by National Federation of Livestock Agriculture Cooperative Associations (ZenChiku-Ren) from July 19 to August 28, 1988. The farm is located in Tochigi prefecture, Japan. Three replicates of sire group were each tested with groups of ten oestrussynchronized sows in the experiment. Each sire group consisted of four Landrace boars which were fullsibs from the same litter. They had been raised and used for natural mating together. The boars were approximately 1 year old. The average body weight of boars was $153.9 \mathrm{~kg}$. Each group consisted of ten crossbred sows which had weaned piglets on the same day. Gonadotropic hormone (Serotropin : $1000 \mathrm{lU}$ ) was injected to all sows in the group on the second day after weaning piglets in order to induce oestrus. At 09.00 on the fifth day after weaning, both the sow and the sire groups were mixed in a mating pen for $24 \mathrm{~h}$, after which they were separated. At five day intervals, the number of boars in the sire group was reduced from four to two and from two to one in turn, and they were respectively assigned to another new post-weaning sow group for $24 \mathrm{~h}$.

Their behavior during each period were recorded by a time-lapse video recorder. The courtship behavior of a boar included "sniffing" (boar sniffs and licks a sow's genito-anal region) ; "head to head" (boar's head to sow's head) ; "nosing" (boar presses his nose against sow's head, shoulder or flank) ; "following" (boar follows a sow) ; "mounting". The ambient temperature was measured every three hours through $24 \mathrm{~h}$. The experiment was replicated three times by using different sire groups.

The mating pen was located in an open barn with half roofed. The size of the pen was $5.4 \times 6.8 \mathrm{~m}$. The floor was flat concrete. The pens had continuous artificial lighting. At $08.00 \mathrm{~h}$ daily, pigs were fed formula feed on the floor.

Before the observation started, identification numbers were painted on the back and both sides of each pig.

The number of mounts and the time spent on courtship behavior by a boar was compared among one-sire, two-sire and four-sire mating by Mann-Whitny U test ${ }^{14}$.

\section{Results}

The time spent on courtship behavior per boar in each mating scheme is presented in Table 1. The time spent on courtship behavior per boar in four-sire mating was significantly longer than that in one-sire mating $(\mathrm{P}<0.05)$. Boars in two-sire mating spent longer times on courtship behavior than boars in one-sire mating $(P<0.10)$. There was no significant difference between four and two-sire mating.

The distribution of courtship behavior of each boar throughout $24 \mathrm{~h}$ on each replicate of four-sire mating is shown in Fig. 1. This figure indicates that the sexual activities of boars within each replicate were reasonably well synchronized.

Table 1. Time spent(s) on courtship behavior per boar in each mating scheme

\begin{tabular}{clll}
\hline \hline & \multicolumn{3}{c}{ Mating scheme } \\
\cline { 2 - 4 } Replication & 4-sire & 2-sire & 1-sire \\
\hline I & 5338 & 8916 & 1082 \\
II & 6090 & 6214 & 4009 \\
II & 4692 & 1825 & 544 \\
\hline Meant standard & $5373 \pm 700^{\text {a }}$ & $5652 \pm 3579^{\text {ab }}$ & $1878 \pm 1865^{\circ}$ \\
\hline
\end{tabular}

Means with different superscripts differ $(p<0.05)$. 


\section{Sexual Behavior in Boars}

The total time spent on courtship behavior by boars at every three hours in each mating scheme is presented in Fig. 2. In all mating schemes, courtship behavior was most active right after boars and sows were mixed at 09.00. Then, the activity decreased toward night and increased again toward morning.

The number of mounts per boar in each mating scheme is presented in Table 2. The average number of mounts in one, two and four-sire mating was $34.2,53.2$ and 14.7, respectively. The notable suppression by one specific boar over mounting behavior of others was not observed. The number of mounts per boar in four-sire mating was significantly more than that in one-sire mating $(\mathrm{P}<0.05)$. Boars in two-sire mating mounted more of ten than boars in one-sire mating $(P<0.10)$. There was no significant difference between four and two-sire mating groups.

\section{Discussion}

The results indicate that the number of boars in a mating pen can affect the time spent on courtship behavior and the number of mounts per boar. Boars in two and four-sire mating groups were sexually more active than boars in single sire mating.

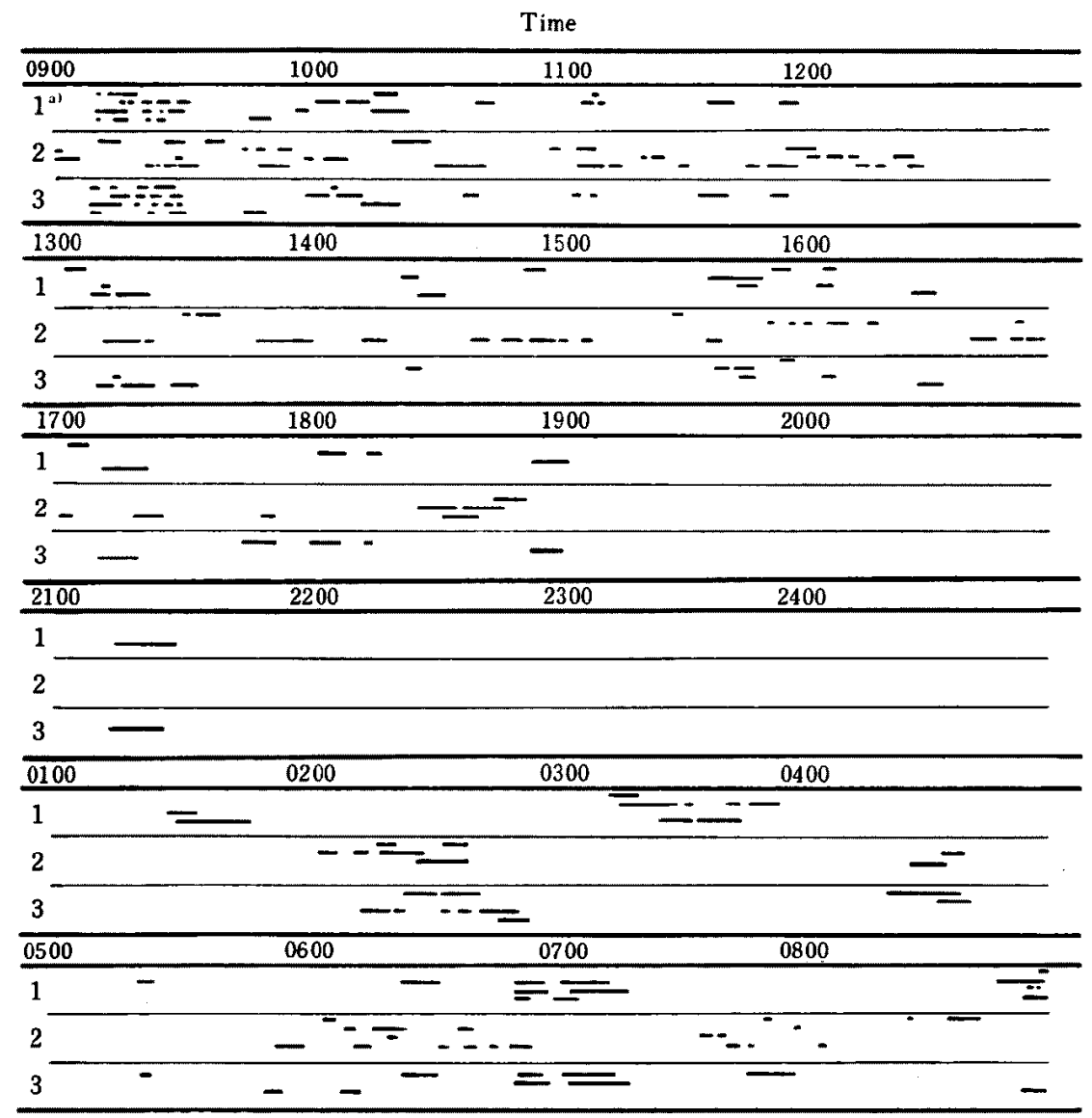

Fig. 1. The distribution of courtship behavior of each boar throughout $24 \mathrm{~h}$ on each replicate of four-sire mating.

a) Replication number 
Replication

1
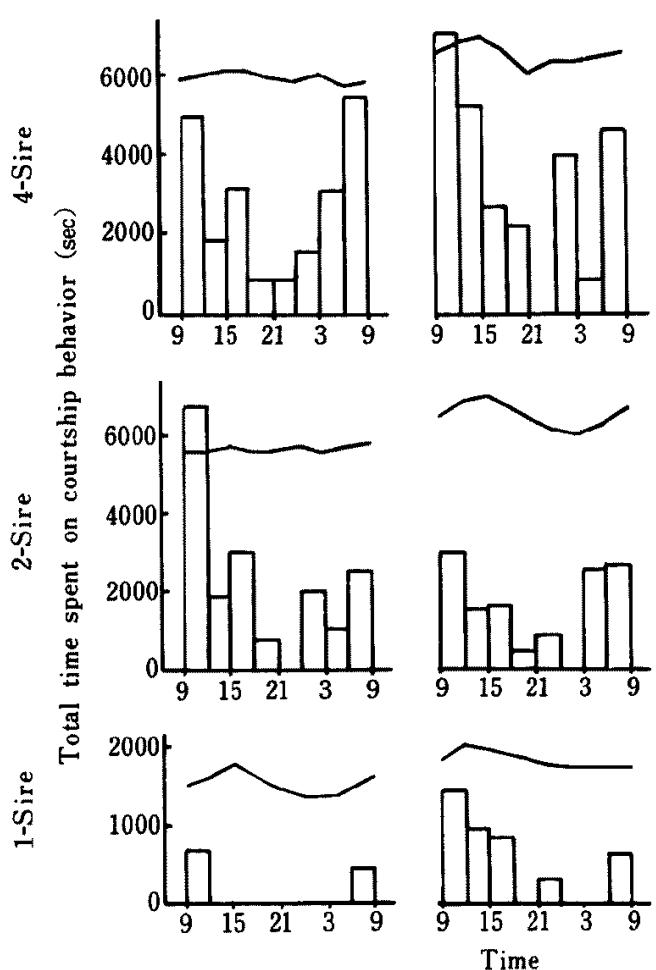

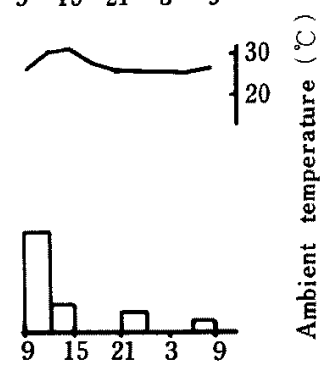

3
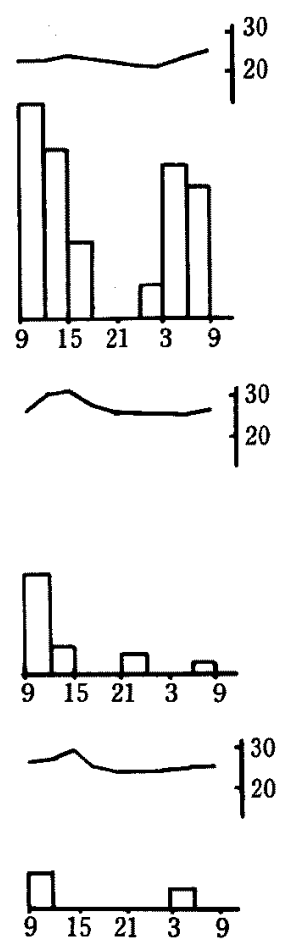

Fig. 2. The total time spent on courtship behavior by boars per every three hours in each mating scheme. The heights represent total courtship of all four boars in 4 -sire, both boars in 2-sire and one boar in 1-sire.

Table 2. Number of mounts per boar in each mating scheme

\begin{tabular}{cllc}
\hline \hline & \multicolumn{3}{c}{ Mating scheme } \\
\cline { 2 - 4 } Replication & 4 -sire & 2-sire & 1-sire \\
\hline I & 35 & 61 & 8 \\
II & 23 & 40 & 29 \\
II & 46 & 15 & 7 \\
\hline Meant standard & $34.2 \pm 11.8^{\mathrm{a}}$ & $53.2 \pm 23.0^{\text {ab }}$ & $14.7 \pm 12.4^{\circ}$ \\
deviation & &
\end{tabular}

Means with different superscripts differ $(p<0.05)$.

Social facilitation of courtship behavior might have occurred in two and four-sire mating, either by watching conspecifics engaged in sexual activities or by being watched by another boar. When one of the boars started sexual activity in four-sire mating, the rest of them had a tendency to follow his acts. There were no leading boars which always initiated sexual activities before others.

Social facilitation of feeding behavior was reported in pigs $^{15)}$, calves ${ }^{16)}$, ponies ${ }^{17)}$ and chickens $^{18)}$. MATTNER et al. ${ }^{13)}$ observed that four bulls became sexually more active than one bull alone. MADER and PRICE ${ }^{19)}$ reported that the sexual performance of beef bulls was enhanced by allowing bulls to observe the copulatory behavior of other males, and to a lesser extent, by being watched by another male. Price et al. ${ }^{20)}$ found that the sexual performance of male dairy goats was significantly enhanced by being watched by another male, by observing the previously 
tested male and by the combination of both managements. On the other hand, Hulet et al. ${ }^{4)}$ reported that the presence of more than one ram in a pen increased only slightly the total number of mating for the pen.

Not only social facilitation or social rivalry among boars but also improvement of sows' receptivity by exposure to more than one boar might have further stimulated boars' sexual activities in multi-sire mating. Many previous studies suggested that factors such as odors and saliva of the boar increased the female's receptivity to mating ${ }^{21-25)}$. More boars in a pen presumably increase the possibility of transmitting more odors and saliva from boars to sows through nosing contact which was reported by TANIDA et $a l .{ }^{26)}$ to be located in the center of courtship behavior in pigs. These results suggest that multi-sire mating could have double effects on increased sexual activity of boars.

LINDSAY et al. ${ }^{7}$ reported that dominant rams could inhibit mating behavior of subordinates without physical contact. BLOCKEY ${ }^{9}$ indicated that older bulls dominated sexual activities within the herd. However, the domination of one boar in courtship and mounting behaviors was not obeserved in the present study. It is probably due to the fact that the sire-group used here was comprised of boars of the same age, which had been raised together as littermates.

Most of the courtship behaviors occurred right after the boars and sows were mixed and between midnight and morning. This trend was consistent through different managements and replicates. These current results agree with the study of TANIDA et al. ${ }^{26)}$ in which two to four boars were assigned to eight sows.

\section{Acknowledgement}

This work was supported in part by a Grandin-Aid for Scientific research (No. 01760220) from the Ministry of Education, Science and Culture, Japan.

\section{References}

1) Guhl, A.M. and D.C. WArren, Poult. Sci., 25 : 460472. 1946.

2) Craig, J.V., B.A. Al-Rawi, and D.D. Kratzer, Poult. Sci., $56: 762-772.1977$.

3) Kratzer, D.D. and J.V. Craig, Appl. Anim. Ethol., 6: 49-62. 1980 .

4) Hulet, C.V., S.K. ERCANBrack R.L. Blackwell, D.A. Price and L.O. Wilson, J. Anim. Sci., 21 : 865869. 1962

5) Shreffler, C. and W.D. Hohenboken, J. Anim. Sci., 39 : 725-731. 1974.

6) Fowler, D.G. and L.D. JEN KINS, Appl. Anim. Ethol., 2: 327-337. 1976.

7) Lindsay, D.R., D.G. Dunsmore, J.D. Williams and G.J. Syme, Anim. Behav., $24:$ 818-821. 1976.

8) Blockey, M.A. de B., Proc. lst World Congr. Ethol. Appl. Zootech., Madrid, pp. 523-530. 1978.

9) Blockey, M.A. de B., Appl. Anim. Ethol., 5 : 15-34. 1979.

10) Rupp, G.P., L. Ball, M.C. SHOOP and P.J. Chenoweth, J. Am. Vet. Med. Assoc., 171 : 639-642. 1977.

11) HoRREL, R.I. and R. KILGOUR, in Ethology of Farm Animals. (Fraser, A.F., ed.) lst edn. 289-312. Elsevier. Amsterdam. 1985.

12) Kilgour, R., B.H. SKarsholt, J.F. SMith, K.J. Bremner and M.C.L. Morrison, Proc. N.Z. Soc. Anim. Prod., 37 : 128-135. 1977.

13) Mattner, P.E., J.M. George and A.W.H. Braden, J. Reprod. Fertil., 36 : 454-455. 1974.

14) Mendenhall, W., R.L. Scheaffer and D.D. WACKERLY, Mathematical statistics with applications. 2 nd edn. 589-594. Duxbury Press, Boston, 1981.

15) Hsia, L.C. and D.G.M. Woon-Gush, Appl. Anim. Ethol, 11 : 265-270. (Short communication). 1984.

16) Barton, M., Appl. Anim. Behav. Sci., 13: 178 (Abstract). 1984.

17) Sweeting, M.P., C.E. Houpt and K.A. Houpt, J. Anim. Sci., 60 : 369-374. 1985.

18) Ross, P.A., J.F. HURnIK and W.D. MORrison, Poultry Sci., 60 : 2176-2181. 1981.

19) Mader, D.R., and E.O. Price, J. of Anim. Sci., 59 : 294-300. 1984.

20) Price, E.O., V.M. Smith and L.S. Katz, Appl. Anim. Behav. Sci., $13: 83-92,1984$.

21) Melrose, D.R., H.C.B. Reed and R.L.S. Patterson, Br. Vet. J., $127: 497-502.1971$.

22) ReEd, H.C.B., D.R. Melrose and R.L.S. Patterson, Br. Vet. J., $11: 131-154.1974$.

23) Perry, G.C., R.L.S. Patterson, H.J.H. MacFie and C.G. Stinson, Anim. Prod., 31 : 191-199. 1980.

24) Hughes, P.E., P.H. Hemsworth and C. Hansen, Appl. Anim. Behav. Sci., 14 : 245-252. 1985.

25) Pearce, G.P. and P.E. Hughes, Appl. Anim. Behav. Sci., $18: 287-299.1987$.

26) Tanida, H., Y. Murata, T. Tanaka and $Y$. 
Yosнiмото, Appl. Anim. Behav. Sci., $22: 245-253$.

1989.

\title{
群飼・自然交配における雄豚頭数の違いが求愛行動 時間および乗駕回数に及ぼす影響
}

\author{
谷田 創・原 勇介・田中智夫・吉本 正
}

麻布大学獣医学部，相模原市 229

\begin{abstract}
群飼・自然交配を行なうにあたって，雄豚頭数の違いが求愛行動時間および乗駕回数に及ぼす影響を 調査することを目的とした．血清性性腺刺激ホルモンを投与した計 90 頭の雑種雌豚と計 12 頭の系統造 成されたランドレース種雄豚を用い，栃木県の全音連研修牧場において夏期 2 カ月間にわたり実験を行 なった，実験区として，雌豚 10 頭群に対して，雄豚 1 頭区，2頭区および 4 頭区を設け，それぞれの 区において雄豚の性行動を 24 時間にわたりタイムラプスビデオレコーターにより調查した。同様の実 娩を計 3 回，反復した，雄豚 4 頭区における各雄豚の求愛行動時間は， 1 頭区に比べて有意に長く，乗 駕回数も有意に多かった，2頭区の雄豚は，1頭区の雄豚に比べて，性的に，より活動的であったが， 両区の間に有意な差は認められなかった４頭区の雄豚の性行動は互いに誘発しあい同調する傾向にあ り，性行動における社会的促進の存在が示唆された。
\end{abstract}

日畜会報, $61(3) ： 283-288,1990$ 